\title{
International patient charters are often nonbinding or feature fuzzy metrics
}

Published at www.cmaj.ca on Aug. 19

I nternational experience with patient charters indicates that nonbinding rights have limited utility, while efforts to quantify the efficacy of such charters have often been hampered by the fact that accountability metrics are often embryonic, if not nonexistent.

The Canadian Medical Association is advocating that Canada adopt such a patient charter as part of its blueprint for transformation of the Canadian health care system (www.cma.ca/multi media/CMA/Content_Images/Inside _cma/Advocacy/HCT/HCT-2010report _en.pdf).

But if international patient charters are an indicator, the value of such a creature will depend on its nature and the extent to which it includes accountability mechanisms.

International charters have sometimes proven ineffective because patient rights are generally articulated as broad expressions of values, rather than concrete directives for systemic change, explains Kathy Kovacs Burns, cochair of the Best Medicines Coalition, a national alliance of advocacy groups that represents people living with chronic diseases. "Charters are value-based documents, so they really pose a challenge for governments to legislate and monitor."

Many developed nations have promulgated patient rights in nonbinding policy documents and some even have enshrined health care rights and responsibilities in legislation. But few provide direct legal recourse for patients who feel their rights have been violated, let alone a mechanism for tracking the impact that such charters have on health care delivery.

France was the first country to draft a patient charter in 1974 . It set out 10 articles covering now-common areas of patient entitlement: access to public services and required care, communication, consent, personal freedom, respect, privacy and confidentiality, and access to administrative and medical records (www.ch-erstein.fr/charte /chartepatient.html).

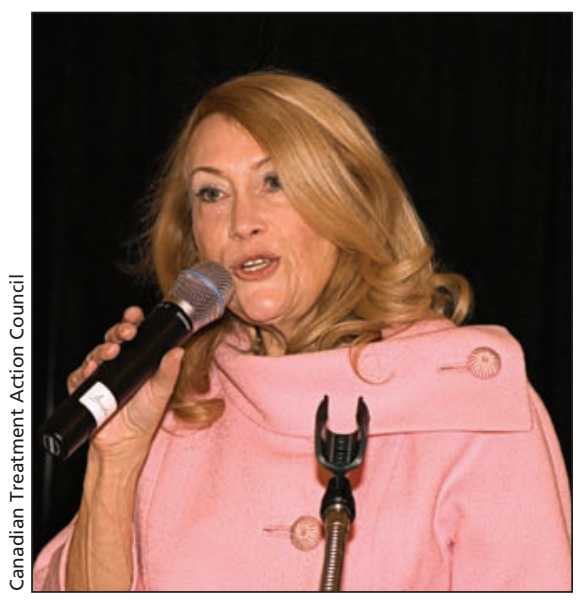

"I've yet to be convinced that a charter of anything gets you very far, unless it's enshrined in law and can be enforced in some meaningful way," says Louise Binder, chair of the Canadian Treatment Action Council, a nongovernmental organization run by and for people living with HIVIAIDS.

It also called upon health care institutions to establish mechanisms for monitoring quality of care, and affirmed the patient's right to complain about his treatment to health care facility directors.

But while groundbreaking in the articulation of rights, the French charter wasn't binding and largely defined patient rights within the context of hospitals, rather than within the health care system at large.

It would be a decade before the United Kingdom reignited interest in patient rights with a document that has since become one of the world's best known and monitored charters. The National Health Service (NHS) Patient's Charter, drafted in 1991 amidst mounting complaints about wait times and quality of care, was unique in its blending of individual rights and concrete services standards (dsp-psd .pwgsc.gc.ca/Collection-R/LoPBdP/BP /prb0131-e.htm).

While the rights covered broad values - such as access to appropriate care and medical records, clear patientphysician communication, the right to seek a second opinion, and the right to have complaints investigated - the standards sought to address such specific concerns as wait times for certain procedures. Those included a maximum waiting period of 13 weeks for nonurgent outpatient appointments in $90 \%$ of cases, a maximum wait of two hours for a hospital bed after admission, and wait times for ambulances not exceeding 14 minutes in cities and 19 minutes in the country.

However, without the force of law, the charter proved to be of limited utility. A London general practitioner claimed the charter "promised people loads of things, but it wasn't the job of the people who wrote the charter to do the delivering — it's like the postman telling the baker to stay open all day. Initially it raised people's expectations and they demanded more, but now that everyone knows the health services is at the breaking point, they've stopped asking" (CMAJ 2001;165[6]:810).

In 1997, a UK Department of Health review of the charter dismissed it as a "disconnected ragbag of so-called service rights and aspirations" (www. dh.gov.uk/en/Publicationsandstatistics /Publications/PublicationsPolicyAnd Guidance/DH_4005210). NHS staff felt the charter was a too "top-down," politically driven document designed to distract an unhappy public without actually addressing their concerns. It engendered a "blame culture" by giving patients rights without any responsibilities, while its emphasis on processing patients as quickly as possible, 
rather than on clinical outcomes, encouraged cheating to comply with admission standards and supported a "tick box" mentality on the part of service providers.

Despite that scathing indictment, the report concluded the charter had succeeded in injecting a more consumerist culture into the health care system and improved the way patients interacted with the system, if not the system itself.

The study led to the 2001 replacement of the charter by a new document, Your Guide to the NHS. Rather than providing rights, it outlined expectations that patients could have in terms of wait times for treatments, ambulance arrival and appointments (www.nnuh .nhs.uk/docs\%5Cleaflets\%5C36.pdf).

But the new document soon attracted criticism as being little more than a watered-down version of the original charter and was replaced in 2009 by the NHS Constitution, which grants patient rights that are intended to be legally enforceable. It also makes nonbinding pledges in the areas of access; quality of care and environment; access to treatments, medicines and screening programs; respect, consent and confidentiality; informed choice; patient involvement in health care and public involvement in the NHS; and complaints and redress (www.dh.gov.uk/en /Publicationsandstatistics/Publications /PublicationsPolicyAndGuidance/DH _113613).

Other countries, meanwhile, have sought to avoid the toothless tiger trap by enshrining patient rights.

In 1992, Finland passed an Act on the Status and Rights of Patients, which regulates a patient's right to information and self-determination, and requires the maintenance of patient records. It also sets up a patient ombudsman and allows patients to submit complaints about their care to the director of their health care unit or any authority in charge of their care. If that care or treatment caused injury or could result in legal action or other disciplinary measure, the patient must be advised on how to pursue redress (www.finlex.fi/en/laki/kaannokset/1992 /en19920785.pdf).

A boom in patient rights legislation ensued in Europe over the next decade as the Netherlands, Israel, Lithuania, Iceland, Latvia, Greece, Norway, Georgia, France, Belgium, Switzerland, Russia, Estonia, Romania and Cyprus enacted laws.

The Netherlands' 1994 act amending its Civil Code, for example, gave patients redress in the courts (www.healthlaw.nl/wgboeng.html).

But only a handful of government followed that legal model, largely for fear of opening themselves to endless and expensive litigation.

While that hasn't occurred in Finland, the fact remains that most nations offer little legal recourse within their patient charters.

And more recent newcomers to the field, such as Hong Kong, Germany, Poland, Slovakia, Austria, Italy and Australia, have opted for nonbinding or voluntary bills of patient rights.

Meanwhile, other than in the UK, there has been little serious investigation into the efficacy of these charters, whether legislation or not.

Australia, for example, has no immediate plans to monitor compliance with its nonbinding charter, says Lidia Horvat, a senior policy officer with the Victoria Department of Health in Australia.

Lack of accountability is "definitely a problem," says Dr. Panayiota Romios, deputy CEO of the Health Issues Centre, an Australian health policy research and action centre. "Charters function best when they're supported by a wide range of legislation, but there should be more information on how this is impacting patients."

It leads Canadian experts to be skeptical about nonbinding bills of rights.

"I've yet to be convinced that a charter of anything gets you very far, unless it's enshrined in law and can be enforced in some meaningful way," says Louise Binder, chair of the Canadian Treatment Action Council, a non- governmental organization run by and for people living with HIV/AIDS.

The United States may become the first nation to seriously track compliance with patient rights legislation, as it prepares for new regulations to enforce strict new rules that will prohibit insurance companies from discriminating against children with preexisting conditions and retroactively cancelling the coverage of policyholders when they get sick or make unintentional mistakes on their applications. The new laws will also eliminate lifetime limits on coverage, allow women to see an obstetrician or gynecologist without a referral and permit people to seek emergency care outside their health plan's provider network.

"I think there are many examples outside [legislation] where there are positive things happening and patients are respected members of the health care team, it's just that it's absolutely not universal," says Myrl Weinberg, president of the National Health Council, which represents more than 100 US healthrelated organizations. "The key is unless there's some strong government agency or authority driving compliance, you need it to be law and you need review."

Although Weinberg expects the US will review compliance with those laws in the future, many are concerned that, as with other nations, enforcement is left to the states and the police, rather than allowing patients recourse through the courts. - Lauren Vogel, CMAJ

DOI:10.1503/cmaj.109-3342

Last of a three-part series on patient charters

Part I: Patients charters: the provincial experience (www.cmaj.ca/cgi/doi/10.1503/cmaj. 109-3339)

Part II: Patient charters all buzz and no bite, advocates say (www.cmaj.ca/cgi/doi/10.1503/cmaj. 109-3340) 